\title{
VASCULAR FLORA OF VINEYARDS IN THE DOC AREA “GIOIA DEL COLLE" (APULIA, SOUTHERN ITALY): PRELIMINARY DATA
}

\author{
Enrico Vito Perrino \& Generosa Calabrese \\ CIHEAM, Agronomic Mediterranean Institute of Bari, via Ceglie 9, 70010 Valenzano (Bari), Italy \\ (enricoperrino@yahoo.it, perrino@iamb.it)
}

Perrino, E. V. \& Calabrese, G.: Vascular flora of vineyards in the DOC area "Gioia del Colle" (Apulia, Southern Italy): preliminary data. Nat. Croat., Vol. 27, No. 1, 41-55, 2018, Zagreb.

A first checklist of the vascular flora of vineyards belonging to the DOC area "Gioia del Colle" is presented. The area is located in centre of the Apulia Region in Southern Italy. In all, 186 species are reported. So far, literature has lacked any systematic data on the flora of vineyards.

Key words: Apulia Region, DOC Gioia del Colle, vineyards, Italy, vascular flora

Perrino, E. V. \& Calabrese, G.: Vaskularna flora vinograda u području zaštićenog geografskog porijekla "Gioia del Colle" (Apulija, južna Italija): preliminarni podaci. Nat. Croat., Vol. 27, No. 1, 41-55, 2018, Zagreb.

U radu se predstavlja prvi popis vaskularne flore vinograda u području zaštićenog geografskog porijekla "Gioia del Colle". Područje se nalazi u centru regije Apulija na jugu Italije. Navodimo ukupno 186 vrsta. Dosad u literaturi nije bilo sustavnih podataka o flori vinograda.

Ključne riječi: regija Apulija, zaštićeno geografsko porijeklo Gioia del Colle, vinogradi, Italija, vaskularna flora

\section{INTRODUCTION}

This research took place in the framework of a cooperative project between research institutes and actors belonging to the whole supply chain of wine production of the area of the DOC (controlled designation of origin, 'notification that a food product be produced within the specified region using defined methods and that it satisfy a defined quality standard') "Gioia del Colle" in Apulia Region, South Italy.

The ancient variety "Primitivo" arrived in Apulia from the Balkan area, on the other side of the Adriatic Sea, thank to the Illyric population. It was marketed in all of the Mediterranean area by the Phoenicians and its cultivation spread in different areas of Apulia. The first document about Primitivo is of 1700 when the priest Don Francesco Filippo Indelicati, of the church of Gioia del Colle, described this variety because he noted that although its buds burst late in spring, the clusters ripen in August, earlier than other varieties. Around 1820 the area of cultivation of Primitivo expanded and attained that of the current area in which the variety is become established. In the last thirty years the habit of cultivating this variety was modified and often it was replaced in the vineyards by more productive varieties. In more recent years, the cultivation of 
table grapes has started to compete for the same land but presently renewed attention is being paid to this ancient variety because of the high quality of wine it yields. Due to the changes in landscape context that occurred after all these trends we wish to verify possible impacts and changes in the flora communities (GAzzetTa Ufficiale della Repubblica Italiana, 1987; Musci, 1919).

Therefore, in order to investigate the on-field flora, 13 vineyards were monitored from 2013 to 2016.

\section{STUDY AREA}

The 13 vineyards are located in six different municipalities falling in the area of cultivation of "Primitivo" (Acquaviva delle Fonti, Adelfia, Conversano, Gioia del Colle, Santeramo in Colle, Sammichele di Bari), in the province of Bari in the Apulia Region (Southern Italy) (Fig. 1). The altitudes included fall between 200 and $500 \mathrm{~m}$ a. s.l., the climate is of the Mediterranean semi-arid type characterized by hot and dry summers and moderately cold and rainy winters. Snow falls at least once a year, especially in the presence of cold air coming from the Balkans. The area is a calcareous highland with a geological substrate mainly consisting of limestones that date back to the Cretaceous period (about 130 million years ago). The typical Mediterranean vegetation of the area includes natural oak woods (mainly of Quercus trojana Webb) referred to Quercetalia pubescenti-petraeae Klika 1933, and evergreen scrubland referred to Pistacio lentisci-Rhamnetalia alaterni Rivas-Martínez 1975, rarer pastures and garrigues.

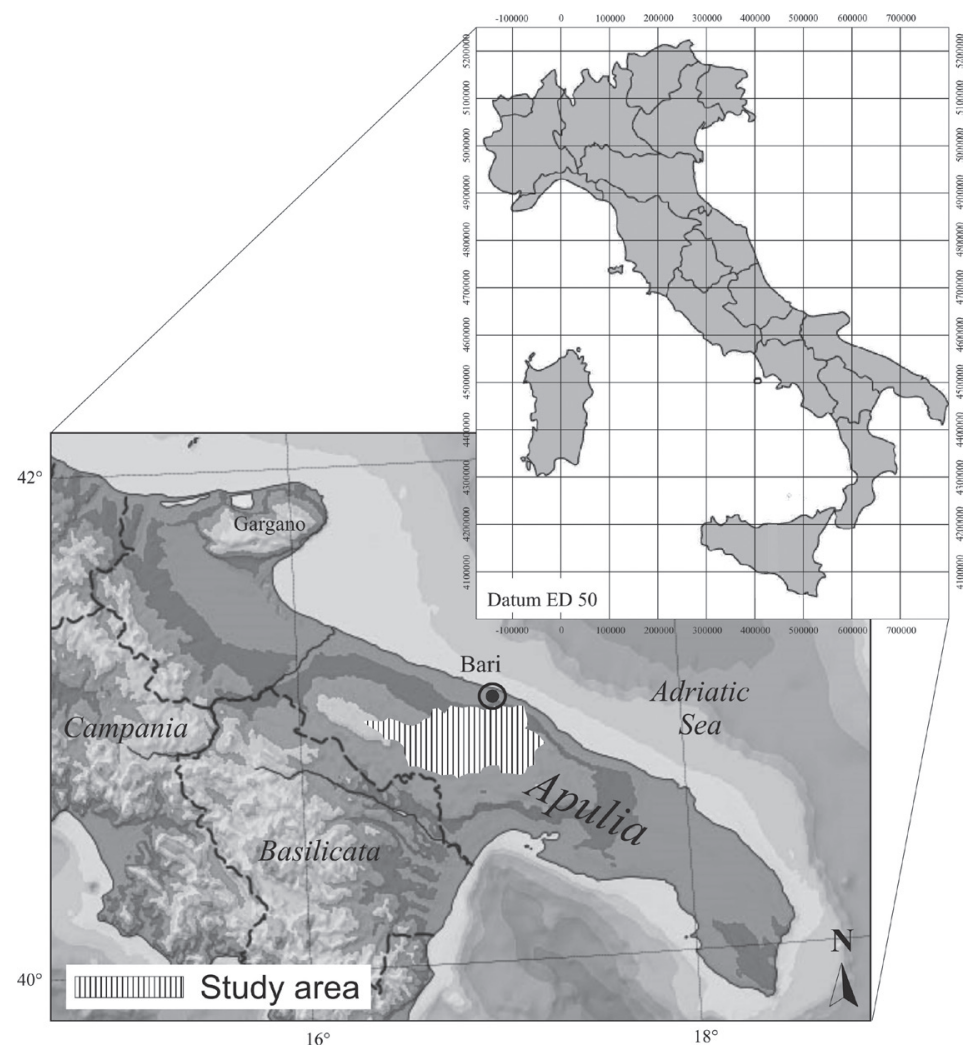

Fig. 1. Study area of surveyed grapevines. 


\section{METHODS}

The study was carried out from 2013 to 2016, and was aimed at investigating the flora of 13 different sites inside the area of cultivation of the ancient variety "Primitivo di Gioia". The list of species was built on the basis of several surveys made for floristic analysis.

Plant analysis was focused on the ecological focus areas*, fields (cultivated surface; here vineyards) and green infrastructure (uncultivated surface, often under human influence: natural hedges, ecotonal belts with plant communities, ruderal habitats etc.). Species were determined according to Tutin et al. (1964-80) and Pignatti (1982). Taxa nomenclature follows Contr et al. (2005) and subsequent integration (ConTi et al., 2007), except for the genus Aegilops L., for which van Slageren (1994), was adopted. The systematics of the families and their arrangement was made according to Peruzzi (2010). The life forms were named according to RAUnKIEAR (1934), while the chorotypes follow the key proposed by PERrino et al. (2014). For species of conservation interest, different acronyms to indicate their vulnerability were used, i.e. VU: vulnerable; PI: phytogeographic interest; CI: Convention on International Trade in Endangered Species (CITES, 1973); $\left({ }^{*}\right)$ common to the four selected and explored olive groves.

In the case of non-native species additional information is indicated by the following categories: archaeophyte (non-native plant species introduced before 1492, i.e. before the era of European colonialism that followed the discovery of America, conventionally approximated to 1500); neophyte (non-native plant species introduced after 1492, i.e. conventionally after 1500, no more observed after 1950); invasive (a subset of naturalized species that spread quickly even at considerable distances from the original sources of propagules); casual occurences (non-native species that grow and reproduce spontaneously but do not form stable populations and depend on a continuous supply of new propagules provided by man) (GALAsso et al., 2018).

The acronyms related to the biological forms and chorotypes are reported in the Appendix.

\section{RESULTS AND DISCUSSION}

In all the vineyards, 186 taxa were recorded, including 155 species and 31 subspecies, belonging to 146 genera and 37 families of vascular flora. The three most represented families are Asteraceae (15.1\%), Poaceae (14.5\%) and Fabaceae (12.9\%) with 79 species and

\footnotetext{
* An Ecological Focus Area (EFA) is an area of land upon which agricultural practices that are beneficial for the climate and the environment are implemented. Since 2015, every farmer in the European Union who claims a direct payment and has more than 15 hectares of arable land is obliged to have $5 \%$ of his arable land covered by ecological focus areas. These are areas which bring benefits for the environment, improve biodiversity and maintain attractive landscapes (such as landscape features, buffer strips, afforested areas, fallowland, areas with nitrogen-fixing crops etc.). Some exceptions to this general rule apply, for example to farmers who have more than $75 \%$ of their area under grassland. The obligation to have $5 \%$ of land covered by ecological focus areas may be increased to $7 \%$ subject to a European Commission report in 2017 and a legislative proposal from the Commission. This obligation is one of three 'greening' measures of the Common Agricultural Policy 2014-2020-the others being the maintenance of permanent grassland and crop diversification. https://ec.europa.eu/agriculture/glossary_en\#glossary-ehttp://ec.europa.eu/agriculture/glossary/pdf/index_en.pdf
} 
subspecies. The other families, each with 12 taxa or fewer, include the remaining 107 taxa (Fig. 2). Many families count common species as compared with other sites in the Apulia Region (i.e. Perrino et al., 2013; Wagensommer et al., 2014).

Asteraceae and Fabaceae are the two most representative families in the fields (45.7\%) (Fig. 3), while in the green infrastructure Fabaceae is replaced by Poaceae, wherein Asteraceae and Poaceae (29.2\%) (Fig. 4) reach lower than the fields. This small difference $(16.5 \%)$ between the two surveyed areas, may be explained by assuming that the flora of the green infrastructure may be influenced more by the flora growing in the natural neighboring habitats.

Sixty-two taxa, $33.3 \%$ of the entire flora, are common to fields and to green infrastructure areas, and $75.8 \%$ of them are therophytes $(\mathrm{T})$. The analysis shows that therophytes, with a presence of $65.6 \%$, are significantly dominant within the group of life forms (Fig. 5). This dominance was expected because annual species are prevalent in bioclimatic regions characterized by hot and dry periods with very short growing seasons and because therophytes are more competitive than other biological forms in habitats prone to human-induced changes (RAUNKIAER, 1934).

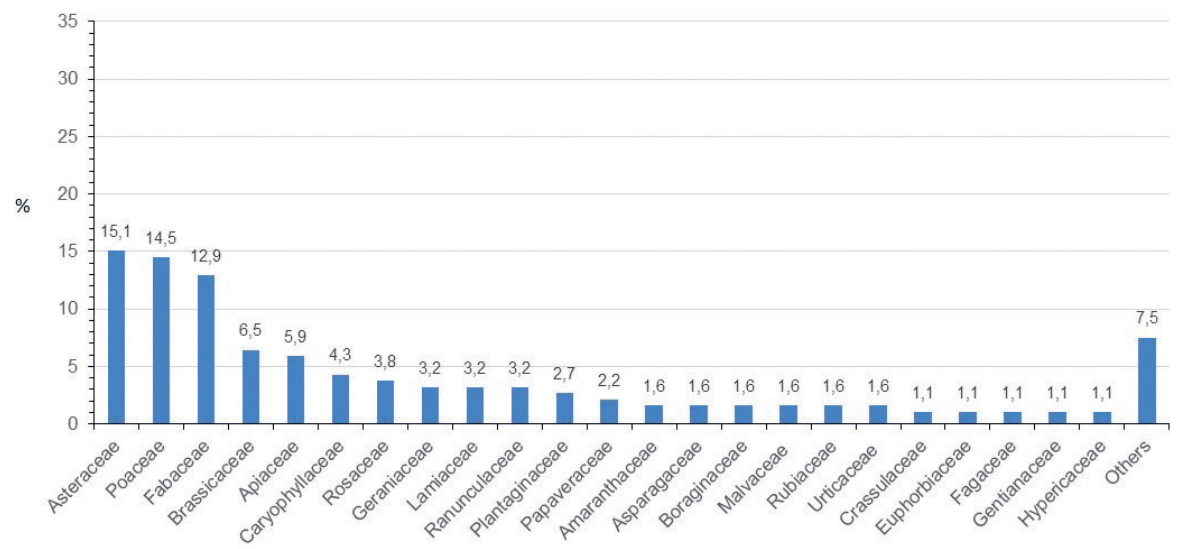

Fig. 2. Species by family in the fields and in the green infrastructure.

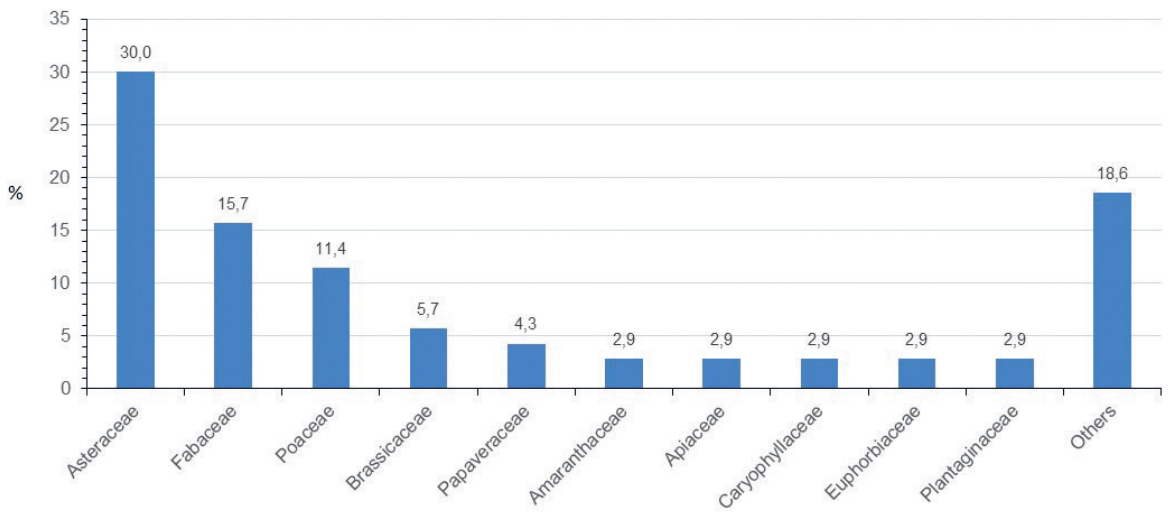

Fig. 3. Species by family in the fields. 


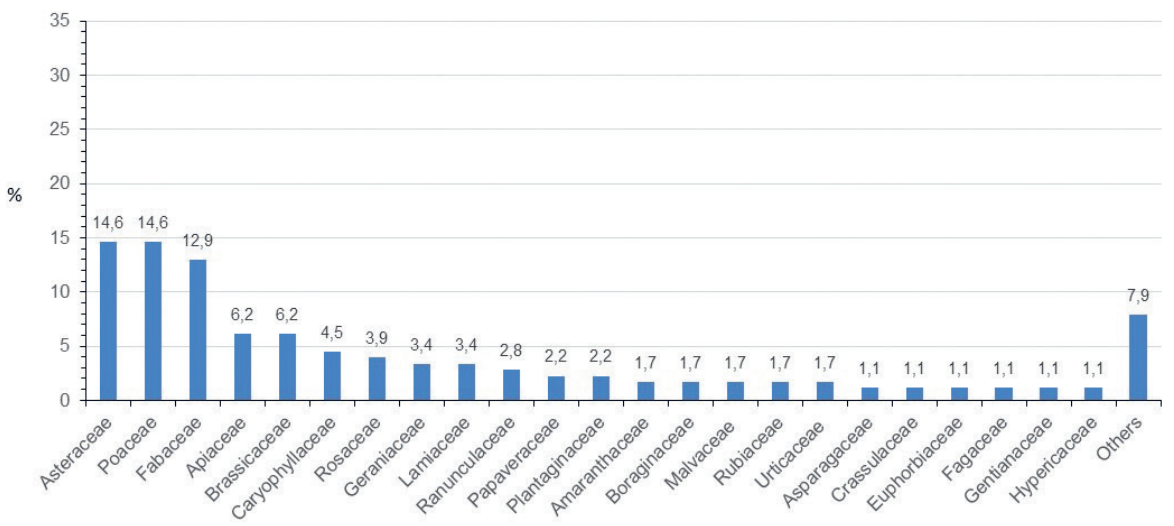

Fig. 4. Species by family in the green infrastructure.

Therophytes are followed by hemicryptophytes $(\mathrm{H})$ with $21.5 \%$, while geophytes $(\mathrm{G})$ and phanerophytes (P) account for $5.9 \%$ and $3.8 \%$ respectively. The occurrence of the other life forms, such as chamaephytes (Ch) and nanophanerophytes (NP), both of which account for $1.6 \%$ of the total, is very low. The comparison between fields (Fig. 6) and green infrastructure (Fig. 7) shows that the therophytes are dominant on other biological forms,

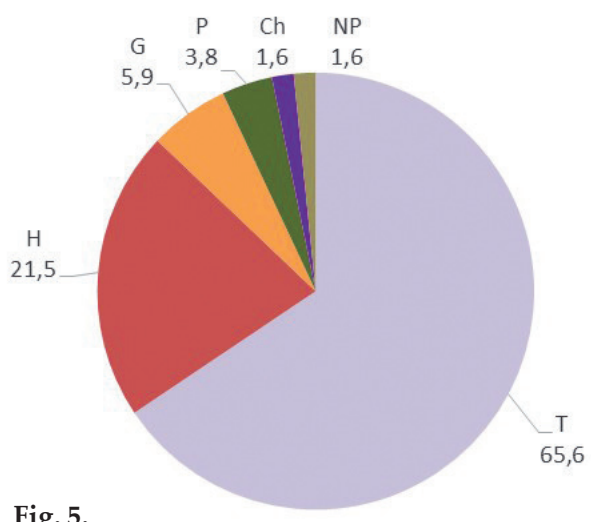

Fig. 5.

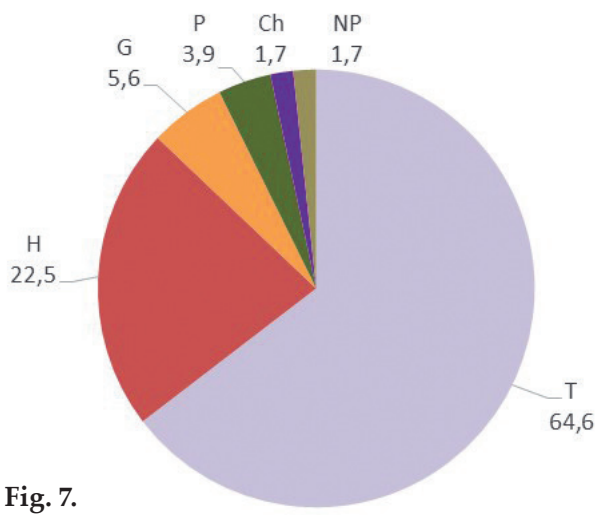

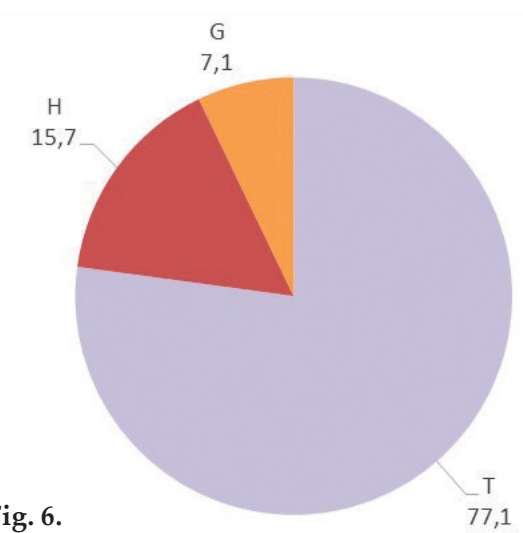

Fig. 5. Life forms in the fields and in the green infrastructure (\%). Ch - chamaephytes; G - geophytes; H - hemicryptophytes; NP - nanophanerophytes; P - phanerophytes; T - therophytes.

Fig. 6. Life forms in the fields (\%). G - geophytes; $\mathrm{H}$ - hemicryptophytes; $\mathrm{T}$ - therophytes.

Fig. 7. Life forms in the green infrastructure. $\mathrm{Ch}$ - chamaephytes; G - geophytes; H - hemicryptophytes; NP - nanophanerophytes; P - phanerophytes; $\mathrm{T}$ - therophytes. 
both in the fields $(77.1 \%)$ and in the green infrastructure $(64.6 \%)$, but in the last the therophytes have a significant decrease to $12.5 \%$ in favour of perennial species $(\mathrm{H}, \mathrm{P}, \mathrm{G}$, $\mathrm{Ch}, \mathrm{NP})$. In fact, in seminatural environments, perennial species have a competitive advantage over some species of therophytes and altogether increase from $22.9 \%$ to $35.4 \%$.

The chorological spectrum (Fig. 8) shows that the Mediterranean stock (see sub-total) is well represented (50.5\%) and it is a little lower than the one known for Apulia flora (52.0\%) (MARCHIORI et al., 2000). It is worth mentioning the dominance of Euro-Mediterranean species (23.7\%) over other Mediterranean types, that enclose the species centered on the Mediterranean coasts and coinciding with the area of the vineyards. In particular, the eu-Mediterranean type reaches $24.2 \%$ in green infrastructure and $22.9 \%$ in the fields and it is considerably higher than the steno-Mediterranean type, $10.0 \%$ higher in fields and 13.5\% higher in green infrastructure) (Figs. 9, 10). Figs. 8, 9 and 10 show also that Eastern Mediterranean range reaches high values, especially at field level where it has the same percentage as the steno-Mediterranean type. The presence of Mediterranean stock in the fields (48.6\%) is slightly different from that in the green infrastructure $(51.1 \%)$ due to the major contribution of species with wide distributions in the fields. There is no species of Northern Mediterranean range, the type listed in olive groves (Perrino \& Calabrese, 2014; Perrino et al., 2014).

Taking into consideration the other chorotypes, out of the total species recorded, the prevailing species are those with a wider distribution $(19.9 \%)$, their percentage being higher in the fields $(22.9 \%)$ than in the green infrastructure $(20.2 \%)$, as already seen in olive groves (PERrino et al., 2014), but in this case with higher percentages. Other chorotypes less present but still worthy of consideration, both in the fields and in the ecological focus areas, are the Paleotemperate $(6.5 \%)$ and the Eurasiatic $(4.8 \%)$ ones. Their percentages change little when the fields (from $4.3 \%$ to $7.1 \%$ respectively) or the green infrastructure are being considered (from $6.2 \%$ to $5.1 \%$ respectively). The

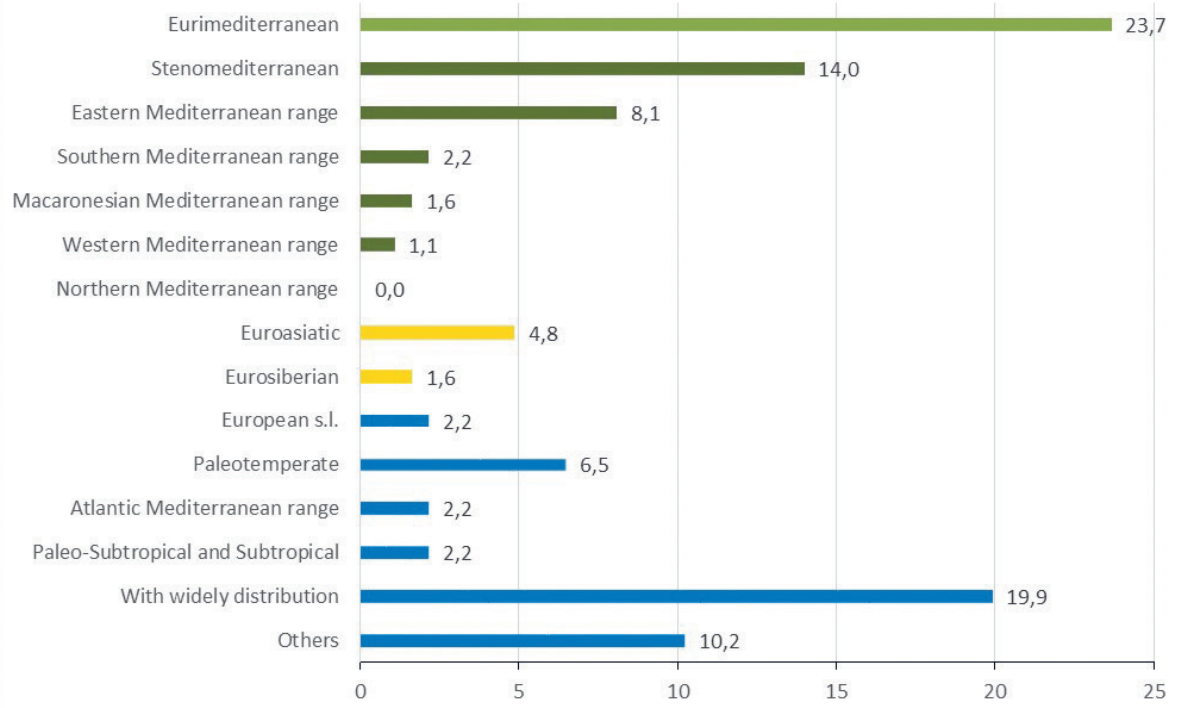

Fig. 8. Chorological spectrum by fields and green infrastructure (\%). 


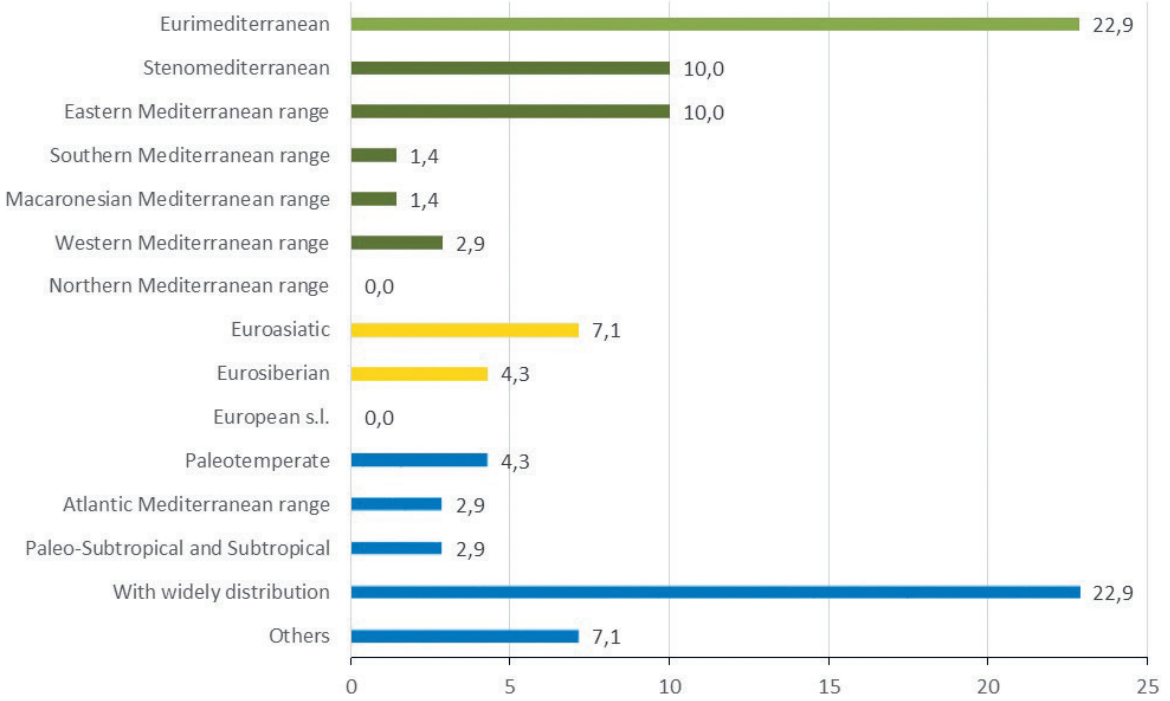

Fig. 9. Chorological spectrum by fields (\%).

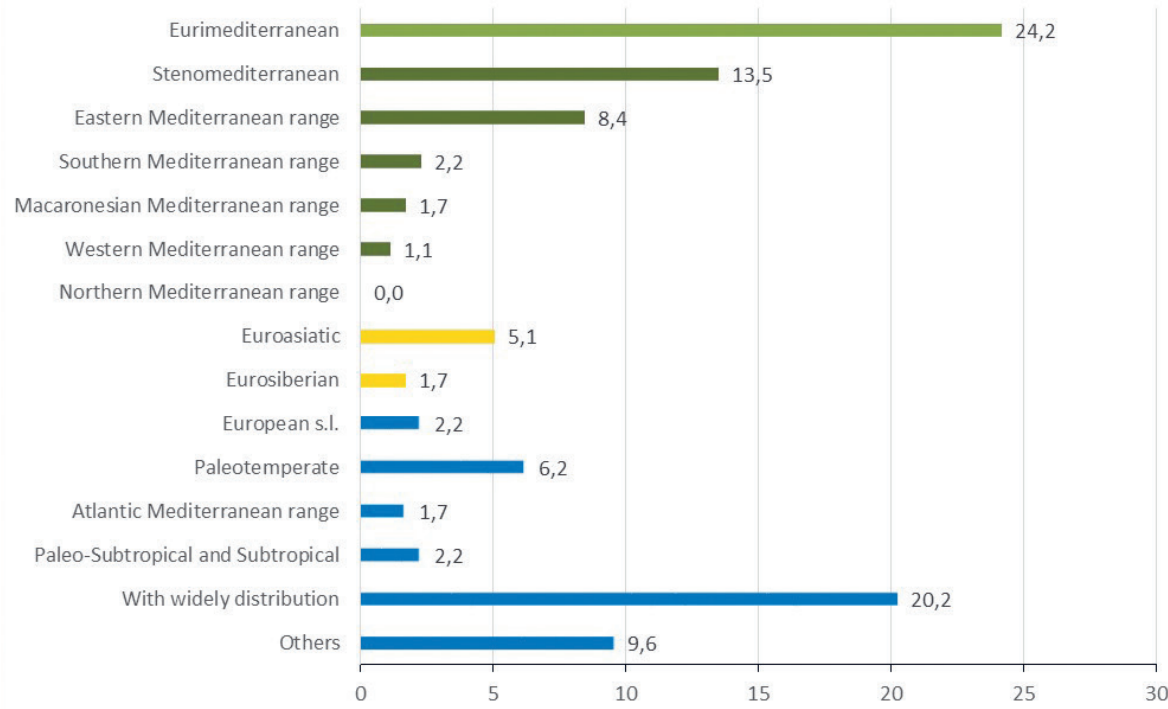

Fig. 10. Chorological spectrum by green infrastructure (\%).

following four chorotypes (Atlantic Mediterranean range, Euro-Siberian, European s.l., Paleo-Subtropical and Subtropical) show variable percentages going from $0.0 \%$ (occurring for European s.1.) to a maximum of 4.3\% (as for Eurosiberian s.1.) always in the fields. It worth noting that the Euro-Siberian entities range from $4.3 \%$ in the fields to $1.7 \%$ in the green infrastructure. The Atlantic Mediterranean range, Euro-Siberian, European s.l., Paleo-Subtropical and Subtropical types considered as a group reach 
8.1\%, lower than the $19.4 \%$ observed in the olive groves (PERrino et al., 2014). The remaining chorotypes reported in the table as "others", appear to be more present in the green infrastructure $(9.6 \%)$ than in the fields $(7.1 \%)$.

The percentage of the Eastern Mediterranean type $(10.0 \%$ in the fields, and $8.4 \%$ in the green infrastructure), reminds us of what has already been observed in olive groves and the correlation with the flora of the eastern geographical areas (PERRINo et al., 2011), but in this case with a more remarkable contribution of the Euro-Mediterranean type than of the steno-Mediterranean.

In the course of the analysis of vineyards, only five non-native species (GALAsso et al., 2018) were found (Tab. 1). Of those, Bidens bipinnata, Pisum sativum, and Triticum turgidum were not listed before in other Apulian vineyards or olive groves for which literature data have been reported. In particular Bidens bipinnata is a neophyte taxon, which spread in recent years, due in particular, to its achens which anchor on workers' clothes and are difficult to remove and spread later on, giving rise to many problems for growers. The presence of Triticum turgidum is due to segetal species in neighboring areas. Two more non-native species were found, probably as a consequence of cultivation and of other agricultural practices: Amaranthus retroflexsus and Erigeron canadensis.

Tab. 1. Non-native species found in the vineyards.

\begin{tabular}{|l|c|c|}
\hline Taxon & Introduction & Status in Apulia region \\
\hline Amaranthus retroflexus L. & Neophyte & Invasive \\
\hline Bidens bipinnata $\mathrm{L}$. & Neophyte & Invasive \\
\hline Erigeron canadensis $\mathrm{L}$. & Neophyte & Invasive \\
\hline Pisum sativum L. & Archeophyte & - \\
\hline Triticum turgidum L. & Archeophyte & Casual occurences \\
\hline
\end{tabular}

\section{Analysis of taxa of conservation interest}

The results show the presence of the following taxa of conservation interest.

Allium atroviolaceum Boiss. [VU]. Place: Adelfia (Bari). НавітAт 92/43/EEC: not identified. Mediterranean-Turanian species reported as having vulnerable (VU) status for the Apulia region (Contr et al., 1997). Its distribution in the Italian peninsula is limited to the Apulia, Basilicata, Abruzzo and Molise Regions (Contr et al., 2005). Its presence was reported in many places of the Apulia Region (i.e. D'Amico et al., 2003; Perrino \& SignORILE, 2009). There will probably be a greater spread at regional level. In the present study the species was observed only in the ecological focus areas of Adelfia grapevine.

Quercus trojana Webb subsp. trojana [PI]. Place: Conversano (Bari). НавIтAт 92/43/ EEC: Quercus trojana woods (code 9250). Mediterranean species with a northeastern range. In Italy it is reported only for Apulia and in the Basilicata Regions (Contr et al., 2005). It is apecies of phytogeographic interest whose habitat is protected by Directive 92/43 EEC (European Commission DG Environment, 2007; Biondi \& Blasi, 2009). The monitoring of this habitat is suggested in a recent contribution (PERRINo \& FANELLI, 2016). 
Ophrys incubacea Bianca [CI]. Place: Santeramo in Colle (Bari). Plant community: uncultivated community (Stellarietea mediae R. Tüxen, Lohmeyer \& Preising ex Rochow 1951); НАвітат 92/43/EEC: not identified. It is a relatively common species in grasslands and uncultivated communities, but relatively rare in the study area. It is a species common in all of the Italian Regions, included in the CITES list.

\section{FLORISTIC LIST}

\section{Monocotyledones}

MAGNOLIIDAE

\section{ORCHIDACEAE}

Ophrys incubacea Bianca - G - Ms - CI

AMARYLLIDACEAE

Allium atroviolaceum Boiss. - G - Mte - VU

ASPARAGACEAE

Asparagus acutifolius L. - NP - Ms

Muscari comosum (L.) Mill. - G - Me

Ornithogalum sp. - G

\section{POACEAE}

Aegilops ovata Auct. - T - Mst

Avena barbata Pott. ex Link - T - Me

Avena sativa L. - T

Briza maxima L. - T - Tps

Bromus diandrus Roth - T - Tpsp

Bromus hordeaceus L. - T - Cs

Bromus madritensis L. - T - Me

Catapodium rigidum (L.) C.E. Hubb. - T - Me

Cynodon dactylon (L.) Pers. - G - C

Dactylis glomerata L. subsp. hispanica (Roth) Nyman - H - Ms

Dasypyrum villosum (L.) P. Candargy - T - Met

Elymus repens (L.) Gould. subsp. repens $-\mathrm{G}-\mathrm{Cb}$

Hordeum murinum L. subsp. leporinum (Link) Arcang. - T - Cb

Lolium multiflorum Lam. subsp. gaudini (Parl.) Schinz \& Thell. - T/H - Me

Lolium rigidum Gaudin - T - Tpsp

Melica ciliata L. - H - Met

Phalaris brachystachys Link - T - Ms

Phalaris paradoxa L. - T - Ms

Phalaris sp. - T

Phleum subulatum (Savi) Asch. \& Graebn. - T - Ms

Phragmites australis (Cav.) Trin. ex Steud. - H/G - Cs

Polypogon monspeliensis (L.) Desf. - T - Tps

Rostraria cristata (L.) Tzvelev - T - Cs

Setaria viridis (L.) Beauv. - T - Cs

Trachynia distachya (L.) Link - T - Ms

Triticum turgidum L. - T-archeophyte casual ocurrences

Vulpia ciliata Dumort. - T - Me 


\section{Dycotiledones}

\section{PAPAVERACEAE}

Fumaria capreolata L. subsp. capreolata - T - Me

Fumaria officinalis L. - H - Mem

Fumaria parviflora Lam. - T - Mt

Papaver rhoeas L. subsp. rhoeas - T - Mes

\section{RANUNCULACEAE}

Adonis annua L. - T - Ew

Consolida sp. $-\mathrm{T}$

Nigella arvensis L. $-\mathrm{T}-\mathrm{Me}$

Nigella ectinsi L. - T - Me

Ranunculus sardous Crantz - T -Me

\section{CRASSULACEAE}

Sedum caespitosum (Cav.) DC. - T - Ms

Sedum dasyphyllum L. - Ch - Me

VITACEAE

Vitis vinifera $\mathrm{L} .-\mathrm{P}$

\section{FABACEAE}

Astragalus hamosus L. - T - Mt

Coronilla scorpioides (L.) W.D.J. Koch - T - Me

Lathyrus sp. - T

Lathyrus ochrus (L.) DC. - T - Ms

Lotus ornithopodioides L. - T - Ms

Medicago arabica (L.) Huds. - T - Mw

Medicago lupulina L. - T - Tmp

Medicago minima L. - T - Tscm

Medicago orbicularis (L.) Bartal. - T-Me

Medicago polymorpha L. - T - Me

Medicago rigidula (L.) All. - T - Me

Medicago sativa L. - H

Medicago truncatula Gaertn. - T - Ms

Melilotus sulcata Desf. - T - Msd

Pisum sativum L. - T - archeophyte

Scorpiurus muricatus L. - T-Me

Trifolium campestre Schreb. - T - Mmpw

Trifolium scabrum L. subsp. scabrum - T - Me

Trifolium stellatum L. - T - Me

Trifolium tomentosum L. - T - Tmp

Vicia sp. - T

Vicia faba L. - T

Vicia lutea L. - T - Me

Vicia sativa L. - T - Cs

ROSACEAE

Crataegus monogyna Jacq. - P - Tmp

Potentilla sp. $-\mathrm{H}$

Prunus dulcis Miller D.A. Webb - P - Msd

Prunus mahaleb L. - P - Esp 
Rosa canina L. - NP - Tmp

Rubus ulmifolius Schott - NP - Me

Sanguisorba minor Scop. subsp. balearica (Bourg. ex Nyman) Muñoz Garm. \& C. Navarro - H - Tmp

URTICACEAE

Mercurialis annua L. - T - Tmp

Parietaria judaica L. - H - Mem

Urtica urens L. - T - Cs

FAGACEAE

Quercus pubescens Willd. subsp. pubescens - P - Esep

Quercus trojana Webb subsp. trojana - P - Mne - PI

EUPHORBIACEAE

Euphorbia helioscopia L. subsp. helioscopia - T - C

Euphorbia peplus L. - T - Esb

SALICACEAE

Populus nigra L. - P - Tmp

HYPERICACEAE

Hypericum perforatum L. - H - Tmp

Hypericum triquetrifolium Turra - $\mathrm{H}$ - Mse

GERANIACEAE

Erodium cicutarium (L.) L'Hér. - T/H - Cs

Erodium malacoides (L.) L'Hér. subsp. malacoides - T - Ms

Geranium molle L. - H - Cs

Geranium purpureum Vill. - T - Me

Geranium rotundifolium $\mathrm{L}$. - T - Tmp

Geranium sp. - T

MALVACEAE

Malva cretica Cav. - T - Ms

Malva parviflora L. - T - Me

Malva sylvestris L. $-\mathrm{H}-\mathrm{Esb}$

RESEDACEAE

Reseda luteola L. - T- Cb

BRASSICACEAE

Capsella bursa-pastoris (L.) Medik. subsp. bursa-pastoris - H - C

Cardamine hirsuta L. - T - C

Diplotaxis erucoides (L.) DC. subsp. erucoides - T- Msw

Diplotaxis tenuifolia (L.) DC. - H - Masb

Hirschfeldia incana (L.) Lagr.-Foss. - H - Mmc

Lepidium draba (L.) Desv. subsp. draba - G/H - Mt

Raphanus raphanistrum $\mathrm{L}$. $-\mathrm{T}-\mathrm{Cb}$

Rapistrum rugosum (L.) Arcang. - T - Me

Sinapis alba L. - T - Mes

Sinapis arvensis $\mathrm{L}$. subsp. arvensis - T - Ms

Sisymbrium officinale (L.) Scop. - T - Cs

ARISTOLOCHIACEAE

Aristolochia rotunda L. - G-Me 
POLYGONACEAE

Polygonum aviculare L. - T - C

CARYOPHYLLACEAE

Arenaria sp. - T

Cerastium glomeratum Thuill. - T - Cs

Petrorhagia sp. - T

Petrorhagia prolifera (L.) P.W. Ball. \& Heywood - T - Me

Polycarpon tetraphyllum L. - T - Me

Silene sp. - T

Silene vulgaris (Moench) Garcke - $\mathrm{H}$

Stellaria media (L.) Vill. subsp. media - T - C

AMARANTHACEAE

Amaranthus retroflexus L. - T $-\mathrm{C}-$ neophyte invasive (native to the Amn)

Beta vulgaris L. $-\mathrm{H}-\mathrm{Me}$

Chenopodium album L. subsp. album - T - Cs

PRIMULACEAE

Anagallis arvensis L. - T - Me

RUBIACEAE

Asperula arvensis L. - T - Me

Galium aparine L. - T - Ea

Sherardia arvensis L. $-\mathrm{T}-\mathrm{Cs}$

GENTIANACEAE

Blackstonia perfoliata (L.) Huds. subsp. perfoliata - T - Me

Centaurium erythraea Rafn - H - Tmp

BORAGINACEAE

Buglossoides arvensis (L.) I. M. Johnst. - T - Me

Echium plantagineum L. - T/H - Me

Heliotropium europaeum L. - T - Met

CONVOLVULACEAE

Convolvulus arvensis L. - G - C

SOLANACEAE

Solanum nigrum L. - T - C

PLANTAGINACEAE

Plantago afra L. - T - Ms

Plantago lanceolata L. - H - Ea

Veronica hederifolia L. - T - Ea

Veronica polita Fries - T - Cs

Veronica sp. - T

SCROPHULARIACEAE

Verbascum blattaria L. - H/T - C

LAMIACEAE

Ajuga iva (L.) Schreb. subsp. iva - Ch - Ms

Calamintha nepeta (L.) Savi-H - Oes

Lamium amplexicaule L. - T - Tmp

Micromeria graeca (L.) Benth. ex Rchb. subsp. graeca - Ch - Ms

Origanum vulgare L. subsp. viridulum (Martin-Donos) Nyman - H - Ea 
Salvia verbenaca $\mathrm{L}$. $-\mathrm{H}-\mathrm{Msa}$

OROBANCHACEAE

Bartsia trixago L. - T - Me

CAMPANULACEAE

Legousia hybrida (L.) Delarbre - T - Ma

ASTERACEAE

Anthemis arvensis L. $-\mathrm{T} / \mathrm{H}-\mathrm{Cs}$

Bidens bipinnata L. - T - Amn - neophyte invasive

Calendula arvensis (Vaill.) L. - T - Me

Carduus pycnocephalus L. subsp. pycnocephalus - $\mathrm{H}-\mathrm{Mt}$

Carlina corymbosa L. - H - Ms

Chondrilla juncea L. - $\mathrm{H}-\mathrm{Me}$

Cichorium intybus L. - H - Tmp

Cirsium arvense (L.) Scop. - G - Ea

Crepis sp. $-\mathrm{T}$

Crepis sancta (L.) Babc. subsp. sancta - T - Me

Crepis vesicaria $\mathrm{L}$. $-\mathrm{T} / \mathrm{H}-\mathrm{Masb}$

Erigeron canadensis L. - T - Avv. - neophyte invasive

Filago germanica (L.) Huds. - T - Ea

Glebionis coronaria (L.) Spach - T - Ms

Glebionis segetum (L.) Fourr. - T - Me

Helminthotheca echioides (L.) Holub - T - Me

Hypochaeris achyrophorus L. - T - Ms

Isatis tinctoria L. subsp. tinctoria - $\mathrm{H}-$ Asse

Lactuca serriola L. - H/T - Mess

Matricaria chamomilla L. - T - Cs

Picris hieracioides L. $-\mathrm{H}-\mathrm{Esb}$

Reichardia picroides (L.) Roth $-\mathrm{H}-\mathrm{Ms}$

Scolymus hispanicus L. subsp. hispanicus - H - Me

Senecio vulgaris L. - T - C

Sonchus asper (L.) Hill - T - Ea

Sonchus oleraceus L. - T - Ea

Sonchus tenerrimus L. $-\mathrm{T}-\mathrm{Ms}$

Urospermum dalechampii (L.) F. W. Schmidt - H - Me

Urospermum picroides (L.) Scop. ex F.W. Schmidt - T - Me

CAPRIFOLIACEAE

Sixalis atropurpurea (L.) Greuter \& Burdet subsp. grandiflora (Scop.) Sold. \& Con$\mathrm{ti}-\mathrm{H}-\mathrm{Ms}$

APIACEAE

Ammi majus L. - T - Me

Bifora testiculata (L.) Spreng. - T - Ms

Daucus carota L. subsp. carota - H - Cs

Elaeoselinum asclepium (L.) Bertol. - H - Ms

Eryngium campestre L. $-\mathrm{H}-\mathrm{Me}$

Ferula communis L. - H - Mes

Foeniculum vulgare Miller - $\mathrm{H}$ - Msd

Foeniculum vulgare Mill. subsp. piperitum (Ucria) Bég. - H - Msd 
Scandix pecten-veneris L. - T - Cs

Tordylium apulum L. - T - Ms

Torilis arvensis (Huds.) Link - T - Cs

\section{CONCLUSION}

Studying the flora of vineyards will enable us to build a database to provide a tool for improving the conservation of the agro-biodiversity of such agro-ecosystems.

The results of the present study constitute the first analytical information on the vineyards' flora; such data are important as they contribute to an increase in the knowledge about the functional biodiversity required to support a more sustainable agriculture.

Present data suggest the need to extend the study to other vineyards of the Apulia region, to other regions of Italy and to the Mediterranean basin, in order to have a more comprehensive picture of the vascular flora and further improve our knowledge of vineyards' agro-ecosystems.

Appropriate planning of agricultural practices and sustainable management of the vineyards would help in meeting environmental goals as well as in considering the economic and social aspects linked to production, meeting the proper conservation requirements of the related ecosystems.

\section{ACKNOWLEDGEMENTS}

The authors wish to thank the Mediterranean Agronomic Institute of Bari (Italy), which made the present study possible. Also, we whish to thank the owners of the vineyards investigated for providing access to their fields, farms and facilities. Finally, the authors wish to thank the referees for their valuable comments and suggestions.

Received November 17, 2017

\section{REFERENCES}

Biondi, E. \& Blasi, C. (Eds.), 2009: Manuale Italiano di interpretazione degli habitat della direttiva 92/43 EEC. http://vnr.unipg.it/habitat/index.jsp.

Conti, F., Abbate, G., Alessandrini, A. \& Blasi, C., 2005: An Annotated Checklist of the Italian Vascular Flora. Palombi Editori, Roma.

Conti, F., Alessandrini, A., Bacchetta, G., Banfi, E., Barberis, G., Bartolucci, F., Bernardo, L., Bouvet, D., Bovio, M., Del Guacchio, E., Frattini S., Galasso, G., Gallo, L., Gangale, C., Gottschlich, G., Grünanger, P., Gubellini, L., Iiriti, G., Lucarini, D., Marchetti, D., Moraldo, B., Peruzzi, L., Poldini, L., Prosser, F., Raffaelli, M., Santangelo, A., Scassellati, E., Scortegagna, S., Selvi, F., SolDano, A., Tinti, D., Ubaldi, D., Uzunov, D. \& Vidali, M., 2007: Integrazione della checklist della flora vascolare italiana. Natura Vicentina, (10) (2006), 5-74.

Conti, F., Manzi, A. \& Pedrotti, F., 1997: Liste Rosse Regionali delle Piante d'Italia. World Wildlife Fund (WWF) Italia. Società Botanica Italiana (SBI). Centro Interdipartimentale Audiovisivi e Stampa, Univ. Camerino, pp 139.

Convention on International Trade in Endangered Species of Wild Fauna and Flora - Cites, 1973 : signed in Washington 3 March 1973. http://www.cites.org/.

D'Amico, F.S., Signorile, G. \& Forte, L., 2003: Aspetti botanici ed ecologici dei "laghi" di Conversano (Ba). Atti Conv. Naz. "Botanica delle zone umide", Vercelli - Albano Vercellese, 10-11 novembre 2000, 231-248.

European Commission DG Environment, 2007: Interpretation manual of European Union habitats (version EUR27). European Commission DG Environment, Brussels.

Galasso, G., Conti, F., Peruzzi, L., Ardenghi, N.M.G., Banfi, E., Celesti Grapow, L., Albano, A., Alessandrini, A., Bacchetta, G., Ballelli, S., Bandini Mazzanti, M., Barberis, G., Bernardo, L., Blasi, 
C., Bouvet, D., Bovio, M., Cecchi, L., Del Guacchio, E., Domina, G., Fascetti, S., Gallo, L.,. Gubellini, L, Guiggi, A., Iamonico, D., Iberite, M., Jiménez-Mejías, P., Lattanzi, E., Marchetti, D., Martinetto, E., Masin, R.R., Medagli, P., Passalacqua, N.G., Peccenini, S., Pennesi, R., Pierini, B., Podda, L., Poldini, L., Prosser, F., Raimondo, F.M., Roma-Marzio, F., Rosati, L., Santangelo, A., Scoppola, A., Scortegagna, S., Selvaggi, A., Selvi, F., Soldano, A., Stinca, A., Wagensommer, R.P., Wilhalm, T. \& Bartolucci, F., 2018: An updated checklist of the vascular flora alien to Italy, Plant Biosystems, 152(3), 556-592. doi:10.1080/11263504.2018.1441197

Gazzetta Ufficiale della Repubblica Italiana, 1987: Parte Prima, Serie generale del 23 ottobre 1987, 248, 1-38.

Marchiori, S., Medagli, P., Mele, C., Scandura, S. \& Albano, A., 2000: Caratteristiche della flora vascolare pugliese. Cahiers Options méditerranénnes, 53, 67-75.

MuscI, G., 1919: “ Il Primitivo di Gioia”, Società Tipografica Editrice Barese.

Perrino, E.V. \& Calabrese G., 2014: Vascular flora of ancient olive groves of Apulia (southern Italy). Natura Croatica, 23 (1), 189-218.

Perrino, E.V., Ladisa G. \& Calabrese G., 2014: Flora and plant genetic resources of ancient olive groves of Apulia (southern Italy). Genetic Resource and Crop Evolution 61 (1), 23-53.

Perrino, E.V., Calabrese, G., Ladisa, G., Viti, R. \& Mimiola, G., 2011: Primi dati sulla biodiversità della flora vascolare di oliveti secolari in Puglia. Inform. Bot. Ital., 43 (1), 39-64.

Perrino, E.V. \& Fanelli G., 2016: 9250 Querceti a Quercus trojana, pp. 238-239. In: Angelini P., Casella L., Grignetti A., Genovesi P., (ed.). Manuali per il monitoraggio di specie e habitat di interesse comunitario (Direttiva 92/43/CEE) in Italia: habitat. ISPRA, Serie Manuali e Linee Guida, 142/2016.

Perrino, E.V., Signorile, G., 2009: Costa di Monopoli (Puglia): check-list della flora vascolare. Inform. Bot. Ital., 41 (2), 263-279.

Perrino, E.V., Wagensommer, R.P., Silletti, G.N., Signorile, G. \& Angiulli, F., 2013: Nuovi dati distributivi e relazione con la Direttiva 92/43/CEE di taxa critici pugliesi dalla Provincia di Bari. Inform. Bot. Ital., 45 (1), 53-62.

Peruzzi, L., 2010: Checklist dei generi delle famiglie della flora vascolare italiana. Inform. Bot. Ital., 42 (1), 151-170.

Pignatti, S., 1982: Flora d'Italia, Vol. 1-3. Edagricole, Bologna.

RAUnKIER, C., 1934: Life forms of plants and statistical plant geography. Oxford University Press, Oxford. Tutin, T.G., Heywood, V.H., Burges, N.A., Moore, D.M., Valentine, D.H., Walters, S.M. \& Webb, D.A. (Eds.), 1964-80: Flora Europaea, 1-5 (1nd edition). University Press, Cambridge.

van Slageren, M. W., 1994: Wild wheats: a monograph of Aegilops L. and Amblyopyrum (Jaub. \& Spach) Eig (Poaceae). Wagningen Agricoltural University, International Center for Agricoltural Research in the Dry Areas, 9 (7), pp. 513.

Wagensommer, R.P., Fröhlich, T. \& Fröhlich, M., 2014: First record of the southeast European species Cerinthe retorta Sibth. \& Sm. (Boraginaceae) in Italy and considerations on its distribution and conservation status. Acta Botanica Gallica: Botany Letters, 161 (2), 111-115.

\section{APPENDIX}

Acronyms of the biological forms and chorologic types

Biological forms. Ch - chamaephytes; P - phanerophytes; G - geophytes; H - hemicryptophytes; NP - nanophanerophytes; $\mathrm{T}$ - therophytes.

Chorologic types. Amn - northern American; Asse - south-eastern Asiatic (steppic); Avv - adventitious; C - Cosmopolitan; Cb - Circumboreal; Cs - Subcosmopolitan; Ea - Euroasiatic; Esb - Eurosiberian; Esep - south-eastern European Pontic; Esp - southern European Pontic; Ew - western European; Ma Medit.-Atlantic; Masb - Medit.-Subatlantic; Me - Eurimedit.; Mem - Eurimedit.-Macaronesian; Mes - eastern Medit.; Mess - Eurimedit. southern-Siberian; Met - Eurimedit.-Turanian; Mmc - Medit.Macaronesian; Mne - North-eastern Medit.; Ms - Stenomedit.; Msd - southern Medit.; Mse - eastern Stenomedit.; Mst - Stenomedit.-Turanian; Msw - western Stenomedit.; Mt - Medit.-Turanian; Mte Medit.-Turanian eastern; Mw - western Medit.; Oes - Orophil south-European; Tmp - Paleotemperate; Tmpw - western Paleotemperate; Tps - Subtropical; Tpsp - Paleo-Subtropical. 
